\title{
COMPARISON OF SINGLE DOSE AND MULTI-DOSE hCG STIMULATION TESTS
}

\author{
TEK DOZ VE ÇOĞUL DOZ hCG UYARI TESTLERININ KARŞILAŞTIRILMASI
}

\author{
Aslı Derya KARDELEN ${ }^{1}$, Esin KARAKILIÇ ÖZTURAN ${ }^{1}$ (D), Leyla ASGAROVA² (D), Ayşe Pınar ÖZTÜRK ${ }^{1}$ (D), \\ Melek YILDIZ1 (D), Şükran POYRAZOĞLU1 (D), Firdevs BAŞ' (D), Feyza DARENDELiLER ${ }^{1}$ (D) \\ 'Istanbul University, Istanbul Faculty of Medicine, Pediatric Endocrinology, Istanbul, Turkey \\ ${ }^{2}$ Istanbul University, Istanbul Faculty of Medicine, Pediatrics, Istanbul, Turkey
}

ORCID IDs of the authors: A.D.K. 0000-0003-0594-8741; E.K.Ö. 0000-0002-8842-1752; L.A. 0000-0001-9339-0500;

A.P.Ö. 0000-0003-3466-2857; M.Y. 0000-0002-6603-2983; S..P. 0000-0001-6806-9678; F.B. 0000-0001-9689-4464; F.D. 0000-0003-4786-0780

Cite this article as: Kardelen AD, Karakilic Ozturan E, Asgarova L, Ozturk AP, Yildiz M, Poyrazoglu S, et al. Comparison of single dose and multi-dose hCG stimulation tests. J Ist Faculty Med. Published online February 14, 2022. doi: 10.26650/IUITFD.949141

\section{ABSTRACT}

Objective: The human chorionic gonadotropin ( $\mathrm{hCG}$ ) stimulation test is widely used to assess testicular steroidogenesis. This test evaluates Leydig cell function and helps to evaluate testosterone synthesis in testicular enzyme defects, hypogonadism, 46,XY sexual development disorders (DSD), and micropenis. This study will compare testosterone responses to a single dose of $5000 \mathrm{lU} / \mathrm{m}^{2}$ and three consecutive days of $1500 \mathrm{IU} / \mathrm{m}^{2} \mathrm{hCG}$ regimens.

Materials and Methods: The study evaluated 18 patients who were admitted with micropenis, hypospadias, or undescended testis (Group 1) and 18 patients with a molecular diagnosis of androgen receptor insensitivity (56\%) or $5 \alpha$ reductase deficiency (44\%) (Group 2). The median (interquartile range; IQR) age of the patients were $1.4(0.8-4.2)$ years for Group 1 and 0.7 (0.3-0.8) years for Group 2. Baseline testosterone levels were checked and after a single dose of hCG $5000 \mathrm{IU} / \mathrm{m}^{2}$ injection into the first group, testosterone levels were observed on day one and day four. In the second group, after the injection of hCG $1500 \mathrm{IU} / \mathrm{m}^{2}$ for three days, testosterone levels were checked on the fourth day.

Results: There was no significant difference in height, weight, BMI SDS, and baseline testosterone levels between groups. After hCG, stimulation testosterone responses did not vary among the groups. Testosterone levels were increased 40-fold and 40.1fold on day four compared to the baseline in Group 1 and Group 2. In Group 1, testosterone response was significantly higher on day four compared to day one $(p=0.001)$.

Conclusions: The hCG tests performed with a single dose or multidoses showed that there was no difference between testosterone responses and these two tests were applicable. Since

\section{ÖZET}

Amaç: hCG uyarı testi, testis steroidogenezini değerlendirmek için yaygın olarak kullanılmaktadır. Bu test hipogonadizm, 46,XY cinsel gelişim bozukluğu veya mikropenisi olan hastalarda Leydig hücre fonksiyonunu, testise bağlı enzim kusurlarını değerlendirmektedir. Bu çalışmada tek doz $5000 \mathrm{IU} / \mathrm{m}^{2}$ ve 3 gün $1500 \mathrm{IU} /$ $\mathrm{m}^{2}$ hCG testlerine testosteron yanıtlarının karşılaştırılması amaçlanmıştır.

Gereç ve Yöntem: Çalışmaya mikropenis, hipospadyas veya inmemiş testisi (Grup 1) olan 18 hasta ile moleküler olarak tanılı androjen reseptör kusuru (\%56) ve $5 \alpha$ redüktaz eksikliği (\%44) olan 18 hasta (Grup 2) dahil edildi. Hastaların median (çeyrekler aralığı) yaşı Grup 1 için 1,4 (0,8-4,2) yıl, Grup 2 için $0.7(0,3-0,8)$ yıl idi. Bazal testosteron düzeyi ölçüldükten sonra ilk gruba tek doz $5000 \mathrm{IU} / \mathrm{m}^{2}$ hCG uygulanarak testosteron düzeyleri 1. ve 4. gün ölçüldü. İkinci gruba ise 3 gün $1500 \mathrm{IU} / \mathrm{m}^{2}$ hCG uygulanarak testosteron düzeyleri 4. gün ölçüldü.

Bulgular: Grup 1 ve Grup 2 arasında boy, kilo, vücut kitle indeksi SDS ve bazal testosteron seviyeleri arasında anlamlı bir fark yoktu. hCG uyarısı sonrasında testosteron yanıtlarında da anlamI fark saptanmadı. Testosteron seviyeleri bazale göre kıyaslandığında 4. günde Grup 1'de 40 kat ve Grup 2'de 40.1 kat artış gösterdi. Grup 1 hastalarında testosteron yanıtı 1. gün ile karşılaştırıldığında 4. günde anlamlı olarak daha yüksek idi ( $p=0,001)$.

Sonuç: Tek doz ve çoğul doz ile gerçekleştirilen hCG uyarı testlerinin sonucunda testosteron yanıtları benzer çıkmış olup bu sonuç her iki testin de uygulanabilir olduğunu göstermiştir. 5000 $\mathrm{IU} / \mathrm{m}^{2}$ testi daha az enjeksiyon gerektirdiği ve uygulaması kolay olduğu için Leydig hücre fonksiyonunu değerlendirmede bu test tercih edilebilir. Yeterli testosteron yanıtı için tek doz $5000 \mathrm{IU} / \mathrm{m}^{2}$

Corresponding author/iletişim kurulacak yazar: aslideryakardelen@gmail.com

Submitted/Başvuru: 18.06.2021 • Revision Requested/Revizyon Talebi: $15.08 .2021 \bullet$

Last Revision Received/Son Revizyon: 10.12.2021 • Accepted/Kabul: 21.12.2021 • Published Online/Online Yayın: 14.02 .2022 
the $5000 \mathrm{IU} / \mathrm{m}^{2}$ hCG test requires fewer injections and is easy to administer, this test may be preferred to an evaluation of the Leydig cell function. For an adequate testosterone response, the researchers suggest measuring testosterone levels on the fourth day after the single dose of $5000 \mathrm{IU} / \mathrm{m}^{2}$.

Keywords: Disorders of sex development, hCG stimulation test, testosterone, $46, \mathrm{XY}$
hCG uygulandıktan sonra 4. gün testosteron düzeylerini ölçmeyi önermekteyiz.

Anahtar Kelimeler: Cinsiyet gelişim bozukluğu, hCG uyarı testi, testosteron, $46, \mathrm{XY}$

\section{INTRODUCTION}

Testosterone is the main product of steroidogenesis, and it is produced by Leydig cells. At birth, following the perinatal decline, the hypothalamic-pituitary-gonadal (HPG) axis is active until 3-6 months of extrauterine life and then lies dormant until the onset of puberty (1). The HPG axis reactivates after the pulsatile secretion of gonadotropin-releasing hormone (GnRH) from the hypothalamus. This reactivation stimulates the secretion of luteinizing hormones (LH) which leads to testicular testosterone production at the onset of puberty (1). Testosterone and its metabolites drive pubertal development of sexual characteristics and sex differentiation of male patients. Therefore, the evaluation of testosterone concentration and its precursors is helpful to identify the disorders of testicular function and development (1).

The human chorionic gonadotropin ( $\mathrm{hCG}$ ) is a glycoprotein which is produced by the human placenta. hCG is usually obtained from the urine of pregnant women (uhCG), however, a recombinant hCG preparation (rhCG) is also produced $(2,3)$. hCG activates the $\mathrm{LH} / \mathrm{hCG}$ receptor on Leydig cells and stimulates sex steroid secretion (2). The hCG stimulation test has been used frequently for the evaluation of testicular steroidogenesis. This test determines Leydig cell function and is used for the evaluation of testicular enzyme deficiencies in hypogonadism, bilateral nonpalpable gonads, micropenis, infertility, $46, \mathrm{XY}$ disorders of sex development, and delayed puberty (4-6). Nevertheless, many different hCG test protocols are reported particularly in terms of the number of injections, application doses, and blood drawing time. Therefore, this study wanted to investigate hCG test protocols with three days $1500 \mathrm{IU} / \mathrm{m}^{2}$ and single dose $5000 \mathrm{IU} / \mathrm{m}^{2}$, and to define the criteria for a normal response and improvement of the procedure.

\section{MATERIALS AND METHODS}

In this study, 36 prepubertal boys were enrolled (Tanner stage I), aged between 0.02-10.4 years old. Eighteen patients were presented with hypospadias, cryptorchidism, or micropenis but a diagnosis had not been obtained yet (Group 1). In Group 1 the hCG stimulation test was performed with one intramuscular injection of
hCG $5000 \mathrm{IU} / \mathrm{m}^{2}$ given early in the morning. Testosterone levels were measured immediately before the injection and then 24 and 96 hours after hCG injection (Group 1).

Another 18 boys had a molecularly verified diagnosis of $5 \alpha$ reductase deficiency $(n=8)$ or androgen insensitivity syndrome $(n=10)$ and received 3 daily $1500 \mathrm{IU} / \mathrm{m}^{2}$ hCG injection. Blood samples for testosterone were taken just before the hCG injection and then 24 hours after the last injection (Group 2).

Anthropometric measurements of the patients for height and weight were taken by the same auxologist. Body mass index (BMI) was calculated with the formula: $\mathrm{BMI}=$ weight $(\mathrm{kg}) /$ height $\left(\mathrm{m}^{2}\right)$. Standard deviation scores (SDS) of these measurements were calculated using national data (7). Haycock formula was used to calculate the body surface area (BSA).

All blood samples were measured at the same endocrine laboratory using the same methods. Plasma T levels were measured by electrochelumiscence (ECLIA) (Cobas Roche Diagnostics, Mannheim, Germany).

The study protocol was approved by the local Ethics Committee (Date: 17.07.2020, No: 985). Written informed consent was obtained from all parents.

\section{Statistical analysis}

The Statistical Package for Social Sciences (SPSS) for Windows 21.0 was used for statistical analysis. The distribution between variables was evaluated with the Shapiro-Wilk test. Comparisons were made between single versus multiple doses, and in Group 1 testosterone 24 hours versus 96 hours after injection. Nonparametric tests were used to compare the study variables. The Mann-Whitney $U$ test was used to compare differences between the two independent groups. The Wilcoxon rank-sum test was performed to compare paired repeated testoterone levels in the groups. The Friedman's two way analysis of variance (ANOVA) by ranks test was used to compare the baseline, first day and fourth day testosterone levels within the same groups. Data presented as median [interquartile range (IQR)]. $p$ value $<0.05$ was accepted as statistically significant. 


\section{RESULTS}

The median age of patients were 1.4 (0.8-4.2) years for Group 1 and 0.7 (0.3-0.8) years for Group 2. The ages of the patients in Group 1 were higher than Group 2. Accordingly, patients in Group 1 had a higher BSA than Group 1. The characteristics of the patients are presented in Table 1. Baseline testosterone levels were prepubertal in four in Group 2 were significantly higher than testosterone levels of day one in Group $1(p<0.001)$. None of the patients developed side effects related to the hCG test. Comparisons of hCG tests are given in Table 2 and Table 3. Figure 1 shows the median testosterone levels of both groups.

Table 1: Characteristics of patients in Group 1 and in Group 2. Data presented as median (interquartile ranges).

\begin{tabular}{|c|c|c|c|}
\hline & $\begin{array}{c}\text { Group } 1 \\
\left(5000 / \mathrm{m} \mathrm{m}^{2}, \text { single dose }\right) \\
\mathrm{n}=18\end{array}$ & $\begin{array}{c}\text { Group } 2 \\
(1500 \text { IU, } 3 \text { days }) \\
n=18\end{array}$ & $p$ \\
\hline Age (years) & $1.4(0.8-4.2)$ & $0.7(0.3-0.8)$ & 0.002 \\
\hline Weight SDS & $-0.6(-1.4-0.4)$ & $0.02(-1.1-0.7)$ & 0.613 \\
\hline Height SDS & $-1.1(-2.1$ and -0.4$)$ & $-0.3(-1.5-0.2)$ & 0.273 \\
\hline BMI SDS & $0.1(-0.7-1.1)$ & $-0.2(-0.9-0.5)$ & 0.273 \\
\hline BSA & $0.5(0.4-0.6)$ & $0.4(0.3-0.5)$ & 0.01 \\
\hline $\begin{array}{l}\text { Diagnosis } \mathrm{n}(\%) \\
\text { Androgen insensitivity syndrome } \\
5 \alpha \text { reductase deficiency }\end{array}$ & NA & $\begin{array}{l}55.6 \\
44.4\end{array}$ & \\
\hline
\end{tabular}

SDS: standard deviation score, BMI: body mass index, BSA: body surface area, NA: not available

Table 2: Comparison of hCG tests. Data presented as median (interquartile ranges)

\begin{tabular}{|c|c|c|c|}
\hline & $\begin{array}{c}\text { Group } 1 \\
(n=18) \\
5000 \mathrm{IU} / \mathrm{m}^{2}, \text { single }\end{array}$ & $\begin{array}{c}\text { Group } 2 \\
(n=18) \\
1500 \mathrm{IU} / \mathrm{m}^{2}, 3 \text { days }\end{array}$ & $p^{*}$ \\
\hline $\begin{array}{l}\text { Testosterone (ng/m } \\
\text { Baseline } \\
\text { Day } 1 \\
\text { Day } 4\end{array}$ & $\begin{array}{c}0.03(0.03-0.03) \\
0.4(0.2-1.7) \\
3.3(1.9-5.3)\end{array}$ & $\begin{array}{c}0.2(0.03-0.8) \\
- \\
4.9(2.8-6.1)\end{array}$ & $\begin{array}{l}0.025 \\
- \\
0.152\end{array}$ \\
\hline $\begin{array}{l}\text { Increase (fold) } \\
\text { Baseline/Day } 4 \\
\text { Baseline/Day } 1\end{array}$ & $\begin{array}{c}40(41.6-179.3) \\
14(5.6-57.7)\end{array}$ & $\begin{array}{c}40.1(3.4-171.8) \\
-\end{array}$ & $\begin{array}{c}0.143 \\
-\end{array}$ \\
\hline
\end{tabular}

*: Mann-Whitney U test

all patients. In Group 1, after the injection of $5000 \mathrm{IU} / \mathrm{m}^{2}$, testosterone levels increased to $0.4(0.2-1.7) \mathrm{ng} / \mathrm{mL}$ and $3.3(1.9-5.3) \mathrm{ng} / \mathrm{mL}$ on day one and day four, respectively. Testosterone level on day one was significantly higher than baseline testosterone levels $(p=0.005)$. In addition, testosterone levels on day four were significantly higher than the baseline $(p<0.001)$. In Group 2 the stimulated testosterone level was $4.9(2.8-6.1) \mathrm{ng} / \mathrm{mL}$ and was significantly higher according to the baseline levels $(p<0.001)$. Peak testosterone levels of Group 1 and Group 2 did not differ $(p=0.152)$ however, both were significantly higher than their baseline values. Testosterone levels increased 40-fold in Group 1 and 40.1-fold in Group 2 compared to the baseline $(p=0.142)$. The testosterone levels of day
Table 3: Comparison of hCG tests in the groups

\begin{tabular}{lcc}
\hline & Group 1 & Group 2 \\
& p & p \\
Testosterone $(\mathrm{ng} / \mathrm{mL})^{\star}$ & $<0.001$ & - \\
Baseline-Day 1-Day 4 & & \\
$\begin{array}{l}\text { Testosterone }(\mathrm{ng} / \mathrm{mL})^{\star *} \\
\text { Baseline-Day 1 }\end{array}$ & 0.005 & - \\
$\begin{array}{l}\text { Testosterone }(\mathrm{ng} / \mathrm{mL})^{\star *} \\
\text { Baseline-Day 4 }\end{array}$ & $<0.001$ & $<0.001$ \\
$\begin{array}{l}\text { Increase testosterone } \\
\text { Day 1-Day 4 }\end{array}$ & 0.005 & - \\
\hline
\end{tabular}

*: Friedman's two-way analysis of variance by ranks, **: Wilcoxon signed-rank test 


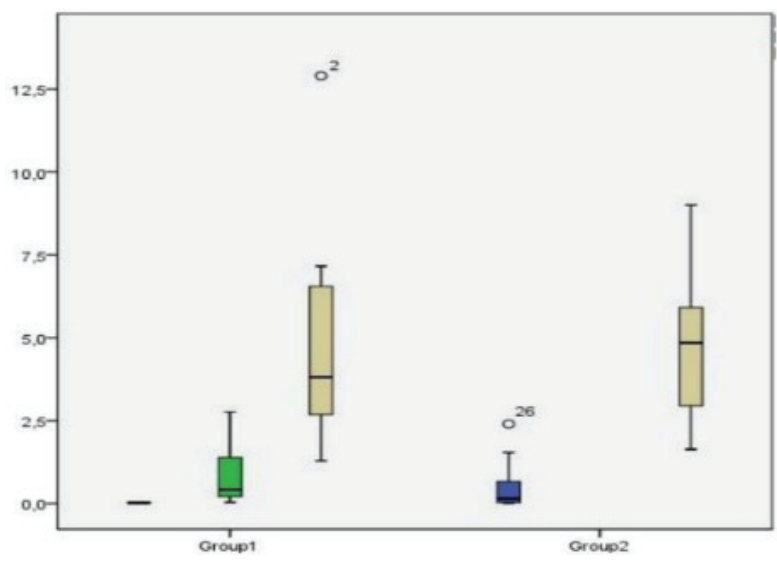

Figure 1: Median testosterone levels of Group 1 and Group 2

\section{DISCUSSION}

This study compared a single dose of $5000 \mathrm{IU} / \mathrm{m}^{2}$ and three consecutive days of $1500 \mathrm{IU} / \mathrm{m}^{2}$ hCG regimens. Peak testosterone levels in both tests were found to be similar. In Group 1, the testosterone level was significantly higher on day four than day one. As a result, a 5000 IU/ $\mathrm{m}^{2} \mathrm{hCG}$ injection and blood drawn on day four was found more pratical than the other options.

The hCG stimulation test is the gold standard test to determine Leydig cell function. In recent years, assays like Ins|3, anti-mullerian hormone (AMH), and inhibin B were identified for the evaluation of male reproductive system (8). However, the hCG stimulation test remains a key step in identifying the testicular hormone secretion. Testosterone responses of hCG stimulation tests help to differentiate bilateral nonpalpable gonads, hypogonadotropic hypogonadism, and constitutional delay of puberty from anorchia and some enzymatic defects of testicular steroidogenesis (9).

Nevertheless, poor standardization of hCG test protocols, lack of normative values, and different biochemical methods for steroid hormone measurements are some of the restrictions of hCG stimulation tests (2). hCG is a polypeptide hormone and has similar structure and action with $\mathrm{LH}$ because it interacts with the same receptor. In clinical practice, hCG is used when LH activity is needed. hCG has a long plasma half-life and stimulates Leydig cell steroidogenesis through the activation of LH/ hCG receptors $(10,11)$.

In recent years, a recombinant hCG (rhCG) has been defined $(250 \mu \mathrm{g} / \mathrm{ampule} ; \quad 6500 \mathrm{IU})$. When compared with uhCG $(5,000 \mathrm{IU}$, single dose) the testosterone responses did not differ. Peak testosterone values were reached 72 hours after injections, and the increase over baseline was significantly high in both groups (12). In another study, a single dose application of 6500 IU rhCG was given to unilateral and bilateral cryptorchid boys and testosterone levels were increased from $10 \mathrm{ng} / \mathrm{dl}$ to $247.8 \pm 135.8 \mathrm{ng} /$ $\mathrm{dL}$ and $253.6 \pm 128.0 \mathrm{ng} / \mathrm{dL}$ : respectively, 7 days after the injection. These studies suggest that rhCG is a favourable test to replace the urinary hCG test for the evaluation of Leydig cell steroidogenesis (3). However, it is more expensive, but rhCG can be used in countries in which uhCG is unavailable (3).

There are a few hCG stimulation tests reported in the literature. Different forms of hCG tests were performed and discrepancies of serum testosterone responses were reported. Previously, 5000IU/1.7 $\mathrm{m}^{2}$ single dose hCG was administered to prepubertal boys and their testosterone levels were measured before the injection and thereafter at $0.5,1,2,3,6,12,24$, and 36 hours, and then daily for 6 days. The early response (at approximately 2-4h) of serum testosterone was absent in all boys, whereas the late response was constant at 2-5 days (13). Ishii et al. performed the hCG test with a dose of $3000 \mathrm{IU} / \mathrm{m}^{2}$ for three consecutive days and gave a cut-off testosterone level of $1.1 \mathrm{ng} / \mathrm{mL}$ for patients who needed further evaluation and hormone replacement treatment was required (14). In another experiment, the peak testosterone level was reached on the third day and the maximal response was maintained through the fifth day, in normal adult males injected with 10.000 IU of hCG (15). In another study, hCG was applied three consecutive days and the daily dose was adjusted according to the age (1 year old, 500 units; 1-10 years, 1000 units; $>10$ years, 1500 units) and testosterone levels were measured 24 hours after the final injection. The study found the positive predictive value of the hCG test to be $89 \%$ and the negative predictive value of the hCG test to be 100\% (16). Kolon et al. investigated 77 prepubertal boys and the hCG dose was applied according to weight $(100 \mathrm{IU} / \mathrm{kg})$ or BSA $\left(5000 \mathrm{IU} / 1.7 \mathrm{~m}^{2}\right)$. Serum testosterone levels were measured at 72 and 96 hours after the injection. The researchers recommended that a single weight or BSA based hCG dose with testosterone measurement after three or four days was cost effective, practical, and reliable in testicular evaluation (17). Great variability in dosing schedules of hCG tests exist and Table 4 lists some of the previously recommended hCG protocols from the literature (13-20).

The main limitations of this study were the absence of a healthy control group and a small number of patients because this was a single center study for a rare disease. Secondly, a genetic analyses could not be obtained from all the patients so Group 1 patients did not have a certain diagnosis. However, most studies of hCG stimulation tests did not have a molecularly diagnosed patient cohort. 


\section{CONCLUSION}

This study investigated the testosterone response after one and three daily doses of hCG protocols in prepubertal boys. Testosterone response in both groups was significantly high according to baseline values. Therefore, the hCG test is a reliable method for the evaluation of testosterone biosynthesis. Peak testosterone levels of both groups did not vary significantly. When a comparison of the easy applicability, practicality, and economy of both tests was done, it is suggested that performing a $5000 \mathrm{lU} / \mathrm{m}^{2}$ rather than the $1500 \mathrm{IU} / \mathrm{m}^{2}$ three day protocol would be the best method.

Informed Consent: Written consent was obtained from the participants.

Ethics Committee Approval: This study was approved by the Ethical Committee of the Istanbul University, Istanbul Faculty of Medicine (Date: 17.07.2020, No: 120372)

Peer Review: Externally peer-reviewed.

Author Contributions: Conception/Design of Study- A.D.K., S..P.; Data Acquisition- A.D.K., L.A., E.K.Ö.; Data Analysis/Interpretation- A.D.K., A.P.Ö., M.Y.; Drafting Manuscript- A.D.K., F.B., M.Y.; Critical Revision of Manuscript- F.D., Ş.P.; Approval and Accountability- A.D.K., E.K.Ö., L.A., A.P.Ö., M.Y., Ş.P., F.B., F.D.

Conflict of Interest: Authors declared no conflict of interest

Financial Disclosure: Authors declared no financial support.

\section{REFERENCES}

1. Palmert MR, Dunkel L, Witchel SF. Puberty, and its disorders in the male. In: Sperling MA (ed). Pediatric Endocrinology $4^{\text {th }}$ edition. Philadelphia: Elsevier Saunders; 2014:pp 697733. [CrossRef]

2. Bertelloni S, Russo G, Baroncelli Gl. Human Chorionic Gonadotropin Test: Old Uncertainties, New Perspectives, and Value in 46,XY Disorders of sex development. Sex Dev 2018;12(1-3):41-9. [CrossRef]

3. Oliveira LR, Homma TK, Woloszynek RR, Brito VN, Longui CA. Gonadal response after a single-dose stimulation test with recombinant human chorionic gonadotropin (rhCG) in patients with isolated prepubertal cryptorchidism. Basic Clin Androl 2016;26:13. [CrossRef]

4. Forest MG. How should we perform the human chorionic gonadotrophin (hCG) stimulation test? Int J Androl 1983;6(1):1-4. [CrossRef]

5. Holterhus PM, Honour JW, Savage MO. Endocrine function of the testes. In: Ranke MB, Mullis PE (eds). Diagnostics of Endocrine Function in Children and Adolescents. Basel: Karger AG; 2011:pp.309-30. [CrossRef]

6. Lucas-Herald AK, Kyriakou A, Alimussina M, GuaragnaFilho G, Diver LA, McGowan R, et al. Serum antimullerian hormone in the prediction of response to hCG stimulation in children with DSD. J Clin Endocrinol Metab 2020;105(5):1608-16. [CrossRef]
7. Neyzi $O$, Bundak R, Gökçay G, Günöz H, Furman $A$, Darendeliler $F$, et al. Reference values for weight, height, head circumference, and body mass index in Turkish children. Journal of clinical research in pediatric endocrinology 2015; 7:280-93. [CrossRef]

8. Valeri C, Schteingart HF, Rey RA. The prepubertal testis: biomarkers and functions. Curr Opin Endocrinol Diabetes Obes 2013;20(3):224-33. [CrossRef]

9. Kogan SJ. Cryptorchidism. In: Kelalis PP, King LR, Belman AB (eds). Clinical Pediatric Urology 3rd edition. Philadelphia: W. B. Saunders;1992:pp. 1063.

10. Casarini L, Santi D, Brigante G, Simoni M. Two hormones for one receptor: evolution, biochemistry, actions, and pathophysiology of LH and hCG. Endocr Rev 2018;39(5):54992. [CrossRef]

11. Trinchard-Lugan I, Khan A, Porchet HC, Munfano A. Pharmacokinetics and pharmacodynamics of recombinant human chorionic gonadotrophin in healthy male and female volunteers. Reproductive Biomedicine Online 2002;4:10615. [CrossRef]

12. Cailleux-Bounacer A, Reznik Y, Cauliez B, Menard JF, Duparc C, Kuhn JM. Evaluation of endocrine testing of Leydig cell function using extractive and recombinant human chorionic gonadotropin and different doses of recombinant human LH in normal men. Eur J Endocrinol 2008;159(2):171-8. [CrossRef]

13. Tapanainen J, Martikainen H, Dunkel L, Perheentupa J, Vihko R. Steroidogenic response to a single injection of hCG in pre- and early pubertal cryptorchid boys. Clin Endocrinol (Oxf) 1983;18(4):355-62. [CrossRef]

14. Ishii T, Matsuo N, Sato S, Ogata T, Tamai S, Anzo M, et al. Human chorionic gonadotropin stimulation test in prepubertal children with micropenis can accurately predict leydig cell function in pubertal or postpubertal adolescents. Horm Res Paediatr 2015;84(5):305-10. [CrossRef]

15. Okuyama A, Namiki M, Koide T, Itatani H, Mizutani S, Sonoda T, et al. A simple hCG stimulation test for normal and hypogonadal males. Arch Androl 1981;6(1):75-81. [CrossRef]

16. Davenport M, Brain C, Vandenberg C, Zappala S, Duffy P, Ransley PG, et al. The use of the hCG stimulation test in the endocrine evaluation of cryptorchidism. $\mathrm{Br} \mathrm{J}$ Urol 1995;76(6):790-4. [CrossRef]

17. Kolon TF, Miller OF. Comparison of single versus multiple dose regimens for the human chorionic gonadotropin stimulatory test. J Urol 2001;166(4):1451-4. [CrossRef]

18. Forest MG. Pattern of the response of testosterone and its precursors to human chorionic gonadotropin stimulation in relation to age in infants and children. J Clin Endocrinol Metab 1979;49(1):132-7. [CrossRef]

19. Bang AK, Nordkap L, Almstrup K, Priskorn L, Petersen JH, Rajpert-De Meyts E, et al. Dynamic GnRH and hCG testing: establishment of new diagnostic reference levels. Eur J Endocrinol 2017;176(4):379-91. [CrossRef]

20. Bertelloni S, Federico G, Baroncelli GI, Cavallo L, Corsello G, Liotta A, et al. Biochemical selection of prepubertal patients with androgen insensitivity syndrome by sex hormone-binding globulin response to the human chorionic gonadotropin test. Pediatr Res 1997;41(2):266-71. [CrossRef] 